Keio J. Med. 30: 37-51, 1981

\title{
STUDIES ON PERINATAL BIODYNAMICS OF IMMUNOREACTIVE LUTEINIZING HORMONE RELEASING FACTOR
}

\author{
MITSUTOSHI IWASHITA \\ Department of Obstetrics and Gynecology, School of Medicine, \\ Keio University, Tokyo, Japan
}

(Received for publication January 15, 1981)

\begin{abstract}
A highly sensitive radioimmunoassay for LH-RF was developed and was used to determine the serum levels of LH-RF of women in normal menstrual cycle, pregnancy from 5 through 40 weeks and throughout 4 different stages of parturition in the same subjects.

Serum concentrations of LH-RF during pregnancy were markedly lower $(4.4 \pm 1.2 \mathrm{pg} / \mathrm{ml})$, compared to those in menstrual cycle $(35.6 \pm 3.5 \mathrm{pg} / \mathrm{ml})$. Among the series of 4 stages of parturition, i.e. (1) during labor, (2) immediately after delivery, (3) 10 minutes after placenta delivery and (4) 4 days after delivery, the mean values for LH-RF were found to be higher in the samples immediately after delivery $(3.7 \pm 0.9 \mathrm{pg} / \mathrm{ml})$ and in those 10 minutes after placenta delivery $(4.4 \pm 0.8 \mathrm{pg} / \mathrm{ml})$. In individual cases, however, three out of 11 women showed peaks of LH-RF level at immediately after delivery and 6 out of 11 showed peaks of LH-RF level in 10 minutes after placenta delivery.

The immunoreactive LH-RF was detected in cord bloods, amniotic fluids, milks and especially large amounts in the placenta by our radioimmunoassay for LH-RF, though it is not known whether they have physiological role and identical to hypothalamic LH-RF.
\end{abstract}

\section{INTRODUCTION}

Luteinizing hormone releasing factor ( $\mathrm{LH}-\mathrm{RF}$ ), one of the hypothalamohypophysiotropic peptide hormones, was isolated and synthesized by Schally et al. and Guillemin et al. in 1971.1-2 Since then radioimmunoassay for LH-RF has been developed by many investigators. ${ }^{3-5}$

The contents of LH-RF in the hypothalami of various animals and the values of $\mathrm{LH}-\mathrm{RF}$ in sera after infusion of large amounts of synthetic LH-RF 
intravenously were successfully measured by these radioimmunoassays within a few years after their establishments, though the amounts of endogenous LH-RF in peripheral blood was too small to determine its values by these earlier radioimmunoassay techniques. Recently, the sensitivity of radioimmunoassay for LH-RF has been improved and immunoreactive LH-RF has been measured in various blood samples. ${ }^{6-9}$ We also developed a highly sensitive and specific radioimmunoassay for LH-RF and reported previously that serum LH-RF levels during pregnancy were lower as compared to those of women in normal menstrual cycles. ${ }^{10}$ The placenta secretes large amounts of sex steroid hormones and others which might influence hypothalamo-hypophysial-gonadal axis to reduce the levels of immunoreactive LH-RF in serum during pregnancy by feedback mechanisms, and significant changes in endocrinological environment in terms of immunoreactive $\mathrm{LH}-\mathrm{RF}$ through parturition, may be induced by the disappearance of these placental hormones.

In this study, we investigated the serum levels of immunoreactive LH-RF in 4 successive stages of parturition by utilizing our newly developed radioimmunoassay for LH-RF. Some hypothalamic peptide hormones have been found in the extrahypothalamic areas. ${ }^{11-12}$ Upton and Amatruda ${ }^{13}$ (1971) reported a corticotropin releasing factor like activity in certain peptides from tumors, Dubois $^{14}$ reported immunoreactive somatostatin in pancreas and Wahlstrom, $\mathbf{T}$. et al. ${ }^{15-16}$ reported immunoreactive $\mathrm{LH}-\mathrm{RF}$ in the human and rat pancreas, though physiological role of these peptide hormones are not known. Another purpose in the present study was to investigate the immunoreactive LH-RF in some human biological fluids during pregnancy, analyzing cord bloods, amniotic fluids, milks as well as the placentas of pregnant women by the radioimmunoassay for LH-RF.

\section{MATERIALS AND METHODS}

\section{Radioimmunoassay}

The antiserum to LH-RF was produced in rabbits by the injection of bovine serum albumine (BSA)-conjugate of LH-RF according to the method described by Makino et al.17 The specificity of the antiserum was examined against thyrotropin releasing factor (TRF), pituitary hormones and LH-RF analogs.

Synthetic LH-RF was radioiodinated by a modified chloramin $\mathrm{T}$ method. Five micrograms of LH-RF were mixed with $1 \mathrm{mCi}$ of ${ }^{125} \mathrm{I}$ for 20 seconds in the presence of $15 \mu \mathrm{g}$ of chloramin $\mathrm{T}$ and the reaction was stopped with $50 \mu \mathrm{g}$ of sodium metabisulfite. Labeled LH-RF and free ${ }^{125} \mathrm{I}$ were separated by ion exchange chromatography on a $200 \times 10 \mathrm{~mm}$ column of carboxymethyl cellulose 
(CMC) eluted with a linear gradient of $0.002 \mathrm{M}$ to $0.4 \mathrm{M}$ ammonium acetate buffer.

The radioimmunoassay procedure was similar as described by Shiina ${ }^{18}$ with slight modification. In brief, $200 \mu$ of antiserum (at dilution of $1: 20,000$ ), $100 \mu l$ of ${ }^{125}$ I-LH-RF $(10,000 \mathrm{cpm} /$ tube, approximately $1000 \mu \mathrm{Ci} / \mu \mathrm{g}), 600 \mu \mathrm{l}$ of extracted samples or standards diluted from $100 \mu \mathrm{l}$ to $500 \mu \mathrm{l}$ with $0.01 \mathrm{M}$ phosphosaline buffer ( $\mathrm{pH} 7.3$ ) and $100 \mu \mathrm{l}$ of $1 \%$ normal rabbit serum with $0.05 \mathrm{M}$ EDTA were incubated for $48 \mathrm{hr}$ at $4^{\circ} \mathrm{C}$. Duplicate standard curves with 7 points ranging $1 \mathrm{pg}$ to $10 \mathrm{ng}$ of LH-RF were included in each assay. One hundred microliter of anti-rabbit $\gamma$-globulin $(1: 100)$ were added and after an additional $24 \mathrm{hr}$, all tubes were centrifuged at $2000 \times \mathrm{g}$ for 20 minutes at $4^{\circ} \mathrm{C}$ and the radioactivity of the precipitate was determined.

The coefficient of variation of intraassay and interassay were $4.2 \%$ and $10.1 \%$ for a concentration of $100 \mathrm{pg} / \mathrm{ml}$, respectively. The recovery of LH-RF from serum was examined by the addition of 8 different concentrations ranging 2.0 to $500 \mathrm{pg}$ of LH-RF to $1 \mathrm{ml}$ of serum treated with charcoal, and LH-RF were quantitatively recovered after acid methanol extraction.

Samples

\section{Samples}

Peripheral blood was taken from; (1) normal pregnant women at 5 to 40 weeks of gestational period that was determined from last menstrual period $(n=47)$; (2) normal menstrual cycling women at outpatient clinic whose menstrual cycle were 28 days $(n=16)$; (3) 4 stages of parturition of each the same subject, these were, during labor, immediately after delivery, 10 minutes after placenta delivery, and 4 days after delivery $(n=12)$.

Cord bloods and amniotic fluids were taken at normal term delivery $(n=8)$. Milks were collected from normal puerperal volunteers at nursing $(n=10)$.

All blood samples including cord bloods were centrifuged immediately after sampling at $2000 \times \mathrm{g}$ for 20 minutes and extracted with 3 times volumes of acid methanol, then with equal volume of petroleum ether. Each samples was dried by a sand heater under the constant nitrogen gas flow. The residue was dissolved in $600 \mu \mathrm{l}$ of $0.01 \mathrm{M}$ phosphosaline buffer and measured for LH-RF by the radioimmunoassay. The placentas were obtained at term delivery $(n=3)$, premature delivery $(n=1)$, and therapeutical abortion $(n=3)$. One gram of fresh villous tissue taken from the placenta was washed with $0.9 \%$ saline immediately following delivery and was homogenized in $2 \mathrm{~N}$ acetic acid. After centrifugation the supernatant was neutralized and lyophilized. The lyophilized samples were dissolved in $600 \mu \mathrm{l}$ of phosphosaline buffer and measured for LH-RF. 


\section{RESULTS}

Preparation of labeled $L H-R F$ and binding with antiserum

A typical pattern for the distribution of radioactivity in $1 \mathrm{ml}$ fraction eluted from a column of CMC was shown in Fig. 1. Fractions were examined for binding with fixed amount of the antiserum. The five peaks were observed. The first peak was free ${ }^{12} \mathrm{I}$ and the fourth peak was monoiode LH-RF in which $60 \%$ of binding to the antiserum was observed.

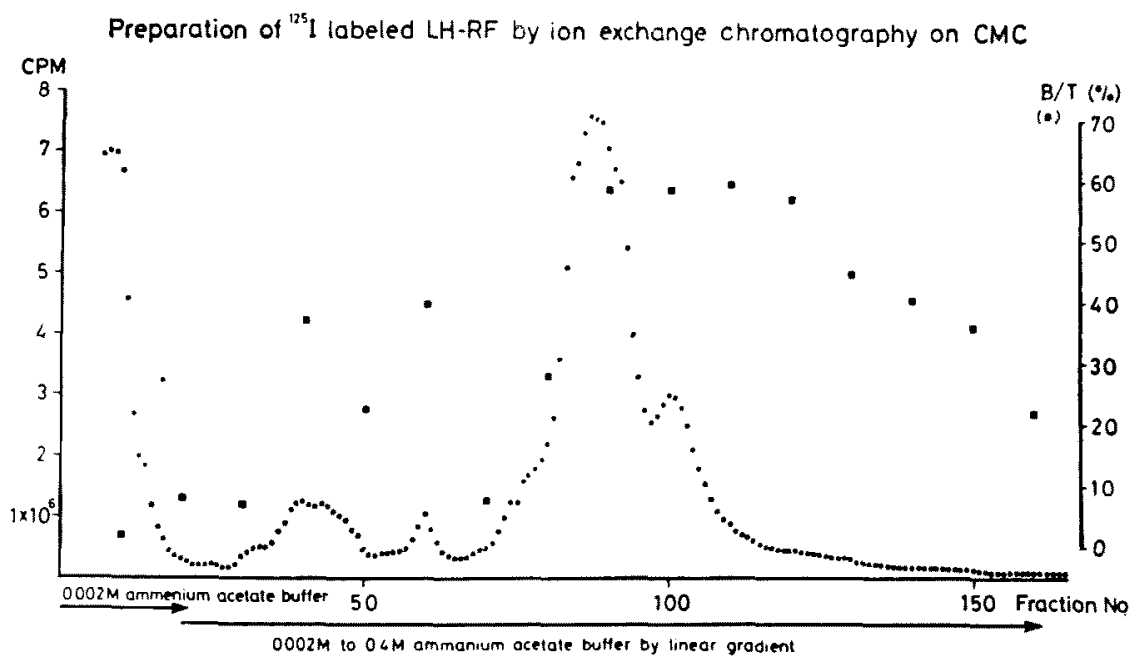

Fig. 1 Distribution of radioactivity in carboxymethyl cellulose (CMC) column of $10 \times 200 \mathrm{~mm}$. The radioiodinated mixture was eluted with $0.002 \mathrm{M}$ to $0.4 \mathrm{M}$ ammonium acetate buffer by linear gradient and $1 \mathrm{ml}$ eluent was collected in each tube. The fourth peak is monoiode LH-RF and the fifth is diiode LH-RF. Closed squares show the binding rates to the antiserum at a final dilution of 1:50,000.

\section{Specificity of antiserum}

Table 1 shows cross-reactivity of antiserum to LH-RF analogs and other hormones. It was found that the antiserum was immunoreactive of various LH-RF analogs with the amide-C-terminal. Synthetic TRF, rat luteinizing hormone, rat follicule stimulating hormone, ovine and rat prolactin, human chorionic gonadotropin, arginine vasopressin and lysine vasopressin did not show significant cross-reactivity with antiserum in the dose range used.

\section{Dose response curve}

Dose response curve for synthetic LH-RF, extracts of the rat hypothalami 
Table 1

The results of the immunological cross reaction of the produced antiserum. The upper half shows the cross reaction rates of the antiserum against analogs and fragments of $L H$-RF. The antiserum obtained had the affinity at the C-terminal of decapeptide. The lower half shows the cross reaction rates of the antiserum against TRF, pituitary hormones and others, Compared to the cross reaction rate against LH-RF as $100 \%$, those of others obtained were less than $0.0001 \%$

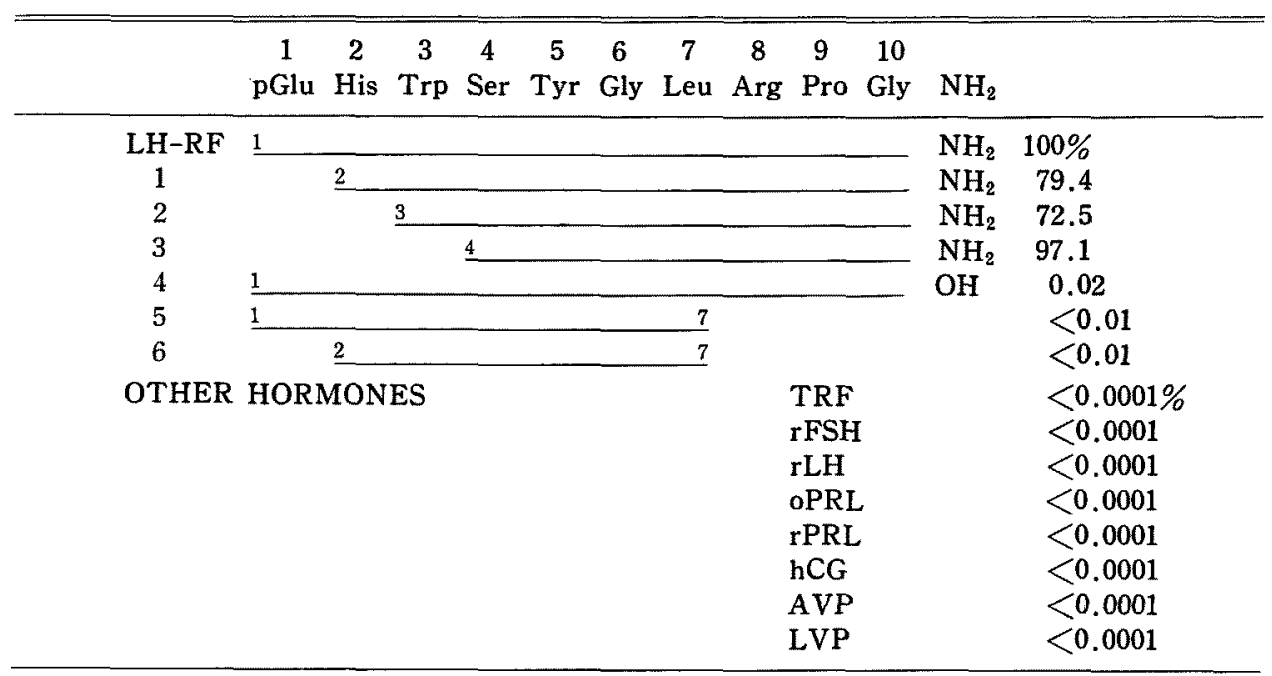

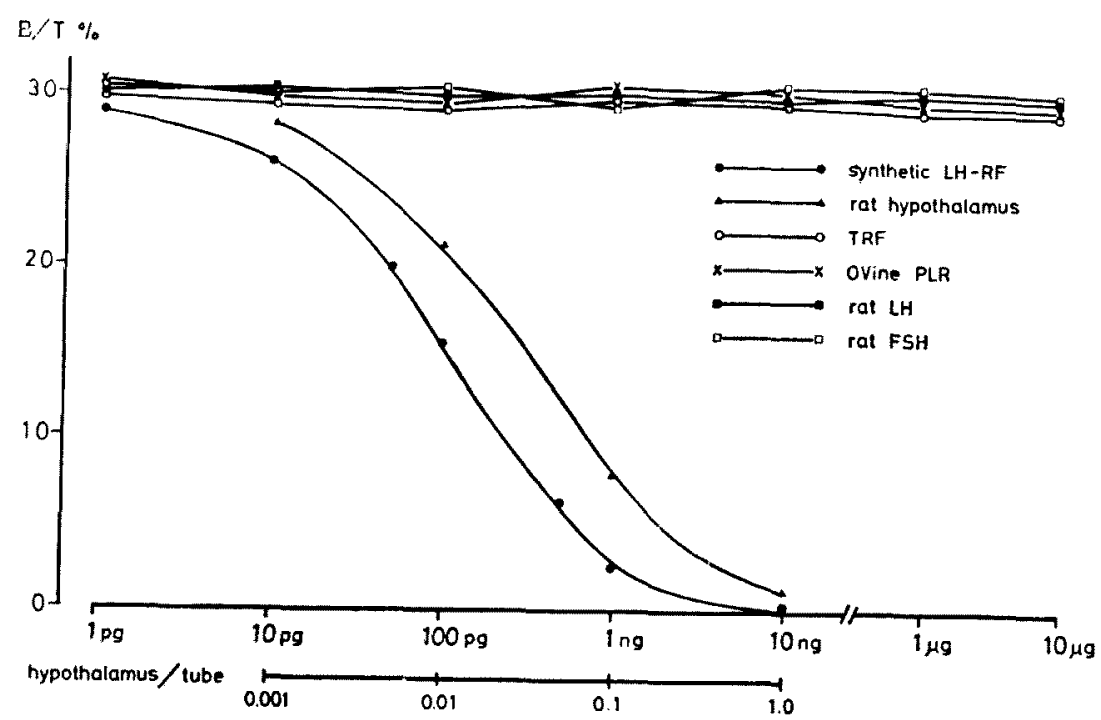

Fig. 2 Dose response curve of LH-RF, rat hypothalamus and other hormones. The antiserum used was a dilution of $1: 100,000$ and was sensitive at the level of $1 \mathrm{pg}$ to $1 \mathrm{ng}$ of LH-RF. 
and other hormones are shown in Fig. 2. The dose response curve for extracts of the rat hypothalami was paralleled to that of LH-RF and the detection limit of the assay under the condition as described was approximately $1 \mathrm{pg}$ per tube.

Recovery of LH-RF from serum

Recovery rates of 8 concentrations of LH-RF added in serum treated with charcoal were shown in Table 2 . The mean of recovery rate was $97.0 \%$.

Table 2

Recovery of LH-RF, addition of 2.0 to $500 \mathrm{pg}$ of $L H-R F$ to $1 \mathrm{ml}$ of serum extracted with acid-methanol extraction

\begin{tabular}{cccc}
\hline \hline $\begin{array}{c}\text { LH-RF added } \\
(\mathrm{pg} / \mathrm{ml})\end{array}$ & Number & $\begin{array}{c}\text { LH-RF Recovered } \\
(\mathrm{M} \pm \mathrm{SD})\end{array}$ & $\begin{array}{c}\text { Recovery } \\
\%\end{array}$ \\
\hline 0 & 5 & N.D. & \\
2.0 & 5 & $1.76 \pm 0.05$ & 88.0 \\
3.0 & 6 & $2.97 \pm 0.16$ & 99.0 \\
5.0 & 4 & $4.87 \pm 0.18$ & 97.4 \\
10.0 & 5 & $10.12 \pm 0.31$ & 101.2 \\
50.0 & 5 & $48.23 \pm 6.12$ & 96.5 \\
100.0 & 4 & $101.32 \pm 8.42$ & 101.3 \\
200.0 & 5 & $191.21 \pm 12.14$ & 95.6 \\
500.0 & 4 & $483.12 \pm 25.42$ & 96.6 \\
\hline
\end{tabular}

Serum levels of LH-RF in women

Serum LH-RF levels during normal pregnancy and in normal menstrual cycle are presented in Table 3,4 and Fig. 3. The LH-RF levels during pregnancy were markedly lower compared with those in menstrual cycle and 21 out of 47 samples during pregnancy were under sensitivity of the radioimmunoassay, while the LH-RF levels of all samples in menstrual cycle were in the detectable range. The mean value during pregnancy and in menstrual cycle were $4.4 \mathrm{pg} / \mathrm{ml}$ and $35.6 \mathrm{pg} / \mathrm{ml}$, respectively.

Serum LH-RF levels in the series of 4 stages of same women's parturition are shown in Fig. 4 and 5 . The mean values, during labor, immediately after delivery, 10 minutes after placenta delivery and 4 days after delivery were 2.8 $\mathrm{pg} / \mathrm{ml}, 3.7 \mathrm{pg} / \mathrm{ml}, 4.4 \mathrm{pg} / \mathrm{ml}$ and $2.2 \mathrm{pg} / \mathrm{ml}$, respectively, and 3 out of 12 women showed the highest LH-RF levels in the samples immediately after delivery and 6 out of 12 showed the peaks in 10 minutes after placenta delivery. The serum 


\section{Table 3}

Serum LH-RF levels through 5 to 40 weelss of normal pregnancy. Closed number shows detectable samples

\begin{tabular}{rrc}
\hline $\begin{array}{c}\text { Weeks of } \\
\text { pregnancy }\end{array}$ & $\begin{array}{c}\text { No. of } \\
\text { samples }\end{array}$ & $\begin{array}{c}\text { Serum LH-RF leves } \\
\text { Mean } \pm \text { S.E. (pg/ml) }\end{array}$ \\
\hline $5-10 \mathrm{~W}$ & $18(8)$ & $3.7 \pm 1.3$ \\
$11-20$ & $9(7)$ & $3.5 \pm 1.5$ \\
$21-30$ & $10(5)$ & $9.9 \pm 4.4$ \\
$31-40$ & $10(6)$ & $1.9 \pm 0.3$ \\
\hline
\end{tabular}

Table 4

Serum LH-RF levels in women with 28 days mentrual cycle

\begin{tabular}{ccc}
\hline \hline $\begin{array}{c}\text { Days of } \\
\text { menstrual cycle }\end{array}$ & $\begin{array}{c}\text { No. of } \\
\text { samples }\end{array}$ & $\begin{array}{c}\text { Serum LH-RF leves } \\
\text { Mean } \pm \text { S.E. (pg/m1) }\end{array}$ \\
\hline $1-12$ & 5 & $29.4 \pm 2.8$ \\
$13-16$ & 6 & $50.6 \pm 4.0$ \\
$17-28$ & 5 & $23.7 \pm 2.2$ \\
\hline
\end{tabular}

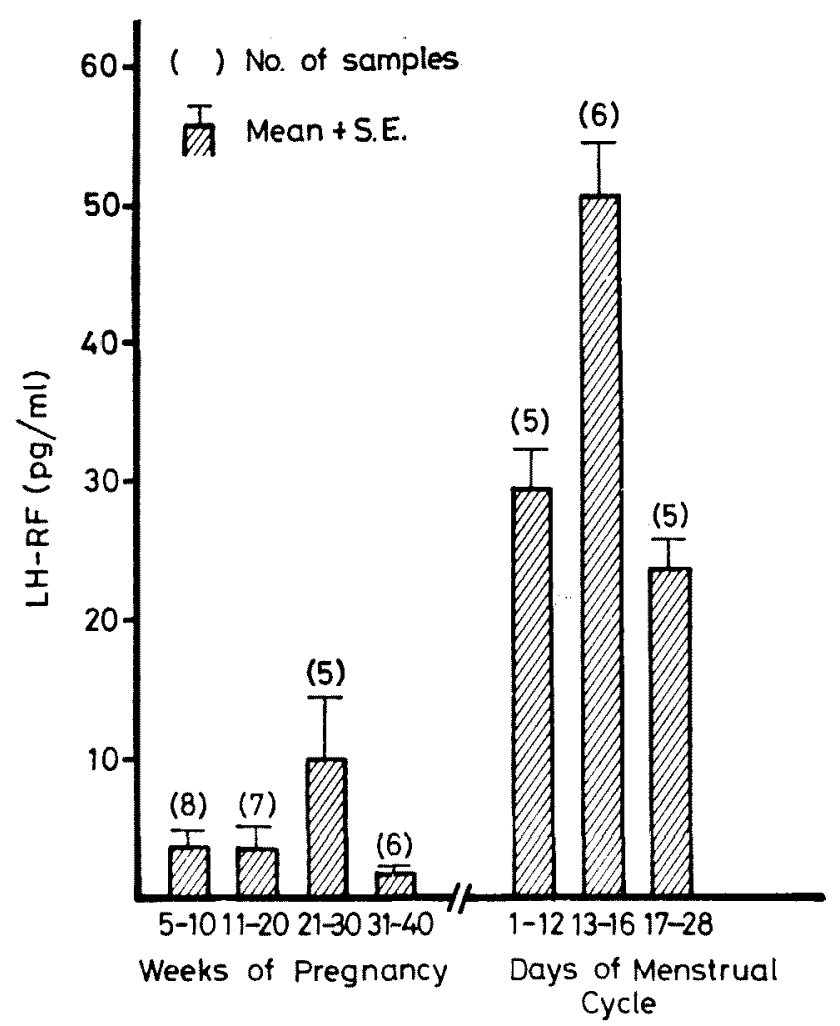

Fig. 3 Serum LH-RF levels in normal pregnancy and 28 days menstrual cycle of women. 


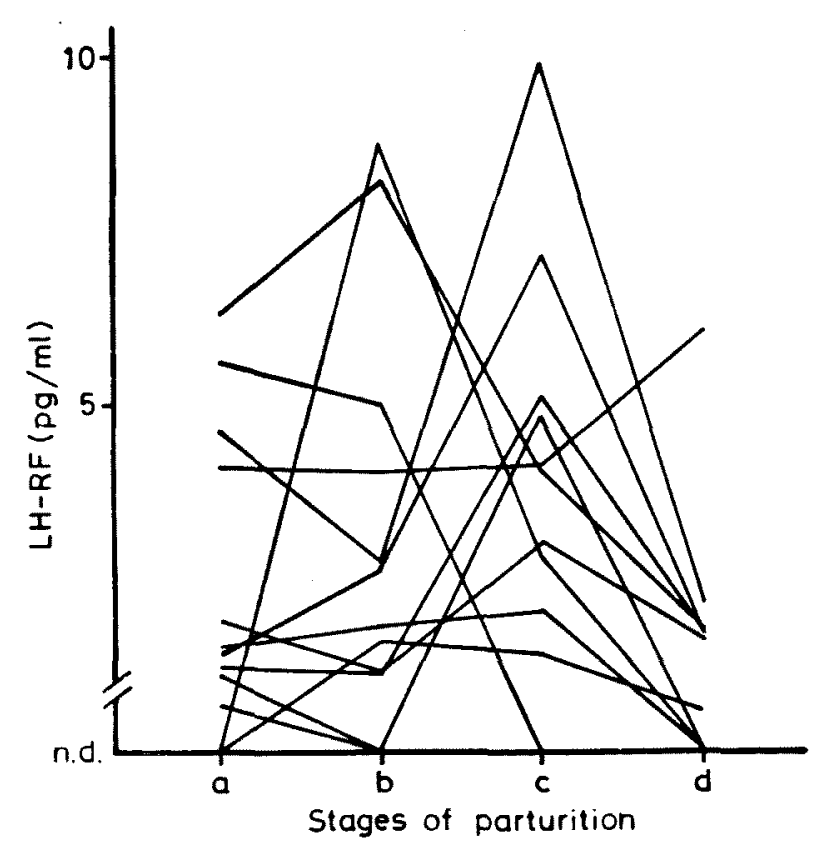

Fig. 4 Serum LH-RF levels in 4 different stages of parturition. a: during labor, $\mathrm{b}$ : after immediate delivery, c: 10 minutes after placenta delivery, d: 4 days after delivery.

LH-RF levels in 4 days after delivery were slightly lower than those in labor.

LH-RF concentration in cord bloods, amniotic fuids and milks

Immunoreactive LH-RF in cord bloods, amniotic fluids and milks were detected and the mean values were $2.0 \mathrm{pg} / \mathrm{ml}(\mathrm{n}=8), 12.9 \mathrm{pg} / \mathrm{ml} \quad(\mathrm{n}=8)$ and 2.0 $\mathrm{pg} / \mathrm{ml}(\mathrm{n}=10)$, respectively (Table $5,6,7)$. Two samples in cord bloods and 4 samples in milks were under sensitivity of radioimmunoassay.

Concentration of $L H-R F$ in the placenta

A large amount of immunoreactive LH-RF was found in the placenta. The mean concentration of 7 samples was $26.1 \mathrm{pg} / \mathrm{mg}$ (Table 8 ). 


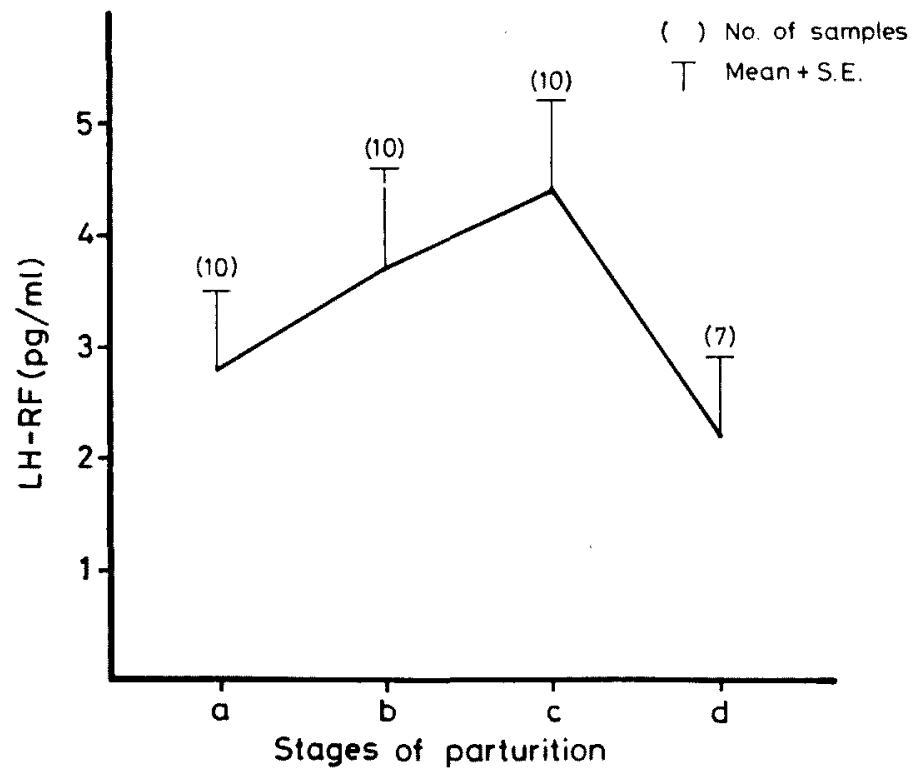

Fig. 5 Mean serum LH-RF levels in the 4 stages of parturition. a, b, c, $d$ same as Fig. 4.

Table 5

The LH-RF levels in cord bloods

\begin{tabular}{cccc}
\hline No. & Age & $\begin{array}{c}\mathrm{LH}-\mathrm{RF} \\
\text { levels }(\mathrm{pg} / \mathrm{ml})\end{array}$ & $\begin{array}{c}\text { Weeks of } \\
\text { pregnancy }\end{array}$ \\
\hline 1 & 27 & 0.7 & 39 \\
2 & 37 & 1.5 & 40 \\
3 & 24 & 1.8 & 41 \\
4 & 32 & 2.5 & 39 \\
5 & 34 & n.d. & 38 \\
6 & 23 & 4.6 & 40 \\
7 & 31 & n.d. & 40 \\
8 & 30 & 0.7 & 39 \\
\hline
\end{tabular}

Mean \pm S.E. $2.0 \pm 0.5$ 
Table 6

The LH-RF levels in amniotic fluids

\begin{tabular}{cccc}
\hline No. & Age & $\begin{array}{c}\text { LH-RF } \\
\text { levels (pg/ml) }\end{array}$ & $\begin{array}{c}\text { Weeks of } \\
\text { pregnancy }\end{array}$ \\
\hline 1 & 24 & 0.6 & 39 \\
2 & 30 & 22.0 & 40 \\
3 & 38 & 50.0 & 40 \\
4 & 26 & 3.5 & 38 \\
5 & 31 & 24.0 & 41 \\
6 & 27 & 0.5 & 39 \\
7 & 32 & 1.3 & 40 \\
8 & 31 & 1.0 & 39 \\
\hline
\end{tabular}

Mean \pm S.E. $12.9 \pm 5.9$

Table 7

The LH-RF levels in human milks

\begin{tabular}{cccc}
\hline No. & Age & $\begin{array}{c}\text { LH-RF } \\
\text { levels (pg/ml) }\end{array}$ & $\begin{array}{c}\text { Days after } \\
\text { delivery }\end{array}$ \\
\hline 1 & 31 & 0.6 & 3 \\
2 & 29 & 4.5 & 4 \\
3 & 27 & 2.7 & 5 \\
4 & 35 & 3.1 & 5 \\
5 & 25 & 0.5 & 6 \\
6 & 27 & n.d. & 6 \\
7 & 30 & n.d. & 7 \\
8 & 30 & n.d. & 8 \\
9 & 32 & 0.3 & 9 \\
10 & 28 & n.d. & \\
\hline
\end{tabular}

Mean \pm S.E. $2.0 \pm 0.7$

Table 8

The concentration of LH-RF in the human placenta

\begin{tabular}{cccc}
\hline \hline No. & Age & $\begin{array}{c}\text { LH-RF } \\
(\mathrm{pg} / \mathrm{mg})\end{array}$ & $\begin{array}{c}\text { Weeks of } \\
\text { pregnancy }\end{array}$ \\
\hline 1 & 28 & 36.2 & 6 \\
2 & 34 & 27.6 & 9 \\
3 & 31 & 41.3 & 10 \\
4 & 26 & 14.0 & 33 \\
5 & 37 & 12.2 & 39 \\
6 & 30 & 31.1 & 40 \\
7 & 27 & 20.1 & 41 \\
\hline
\end{tabular}

Mean \pm S.E. $26.1 \pm 4.2$ 


\section{DISCUSSION}

The iodination of LH-RF was successfully achieved by a slightly modified chloramin $\mathrm{T}$ method and separation of the labeled LH-RF by using CMC column in linear gradient was sufficient enough to purify monoiode LH-RF from diiode LH-RF using this method.

The antiserum used was highly specific to LH-RF and showed immunological affinity with the amide-C-terminal of LH-RF. It bound approximately $30 \%$ of the labeled LH-RF in the absence of any unlabeled hormone at a final dilution of $1: 100,000$.

The serum levels of LH-RF during pregnancy were lower than those in normal menstrual cycle. During pregnancy, the mean level of serum LH-RF was reduced to $12.4 \%$ of those in normal menstrual cycling women. Further, 21 out of 47 samples during pregnancy were undetectable while all samples in menstrual cycle were detected by our assay, supporting a hypothesis that gonadotropic function of hypothalamo-pituitary axis was suppressed during pregnancy. Serum LH levels during pregnancy measured by LH- $\beta$ subunit radioimmunoassay has been reported to be lower than those in normal menstrual cycle ${ }^{19}$ and there were also some reports that pituitary response to LH-RF during pregnancy are suppressed.20-23 These results also support this hypothesis.

The placenta produces sex steroid hormones and protein hormones including human chorionic gonadotropin (hCG) and FSH like substance. ${ }^{24}$ Furthermore, a large amount of immunoreactive LH-RF was found in the placenta in this study. Therefore the most reasonable explanation for the suppression of the pituitary function during pregnancy might be due to negative feedback action of placental hormones.

The serum concentrations of LH-RF both immediately after child delivery and 10 minutes after placenta delivery were increased as compared to those in labor, although the serum concentrations in labor were slightly higher than those of during pregnancy at 31 to 40 weeks of gestational period (Fig. 4 and Fig. 5). In addition, peaks of LH-RF were observed in 3 out of 12 women at immediately after delivery and in 6 out of 12 women at 10 minutes after placenta delivery, while only 3 women showed the peaks during labor or 4 days after delivery. One of the possible explanations of these results is the rebound action of the hypothalamus induced by disappearance of placental negative feedback. However, this hypothesis may not explain the LH-RF peaks observed after immediate delivery since placental sex steroid hormones and hCG are able to be transferred to peripheral blood but their half-lives are not so short that they induce hypothalamic rebound action. In case of placental immunoreactive LH-RF, its half-life is 
enough short to induce rebound action of hypothalamus although LH-RF in the placenta is not seemed to be transferred into peripheral blood because serum LH-RF levels during pregnancy were markedly lower compared with the content of LH-RF in the placenta. The another possible explanation is that placental $\mathrm{LH}-\mathrm{RF}$ penetrates into peripheral blood at separation of the placenta from the uterine wall. If serum LH-RF peak could be observed immediately after delivery, this would support this hypothesis.

Immunoreactive LH-RF was also found in cord bloods, amniotic fluids, and milks in this study. In case of cord bloods, the placenta or fetus might be considered as source of LH-RF, since considerable amounts of LH-RF were found in fetal hypothalamus ${ }^{20-26}$ and in human placenta by our radioimmunoassay measurements as well as by those of other investigators. It is not known, however, whether immunoreactive LH-RF in cord blood has any physiological role. It is not also clear if immunoreactive $\mathrm{LH}-\mathrm{RF}$ is discharged from the placenta or fetal hypothalamus into the cord blood.

The immunoreactive LH-RF in amniotic fluid may come from either (1) amniotic membrane, (2) placenta or (3) fetus, though there is no evidence that the amniotic membrane produces immunoreactive LH-RF that might be easily transferred from the amniotic membrane to amniotic fluid. If LH-RF in amniotic fluid has placental origin, there is no direct explanation how it is transferred from the placenta. As described above, there is a large amount of LH-RF in the fetal hypothalamus and it might be secreted into fetal urine. Thus this immunoreactive LH-RF in amniotic fluid may have fetal origin though its physiological significance is uncertain and there is no report that immunoreactive $\mathrm{LH}-\mathrm{RF}$ in amniotic fluid as well as in cord blood is identical to hypothalamic LH-RF.

The biologically active LH-RF in milk of man, cow and rat was reported by Baram and $\mathrm{Koch}^{27}$ (1980). They presumed that its physiological role was to elevate serum gonadotropin levels in neonate which pituitary is not yet functionally linked to the hypothalamus and was to musculinize male hypothalamus by causing the release of testicular steroids in rat though its origin is not yet known.

Siler-Khodr and Khodr have reported the presence of immunoreactive LH-RF in the human placenta and also demonstrated its localization by using immunofluorescence technique. ${ }^{28-31}$ The concentration of immunoreactive LH-RF were in good agreement with those found in our study. Furthermore, they speculated its physiological role to regulate hCG secretion. The placenta might act as the center of regulation and production of some hormones when the hypothalamus might be suppressed during pregnancy. Further, some other hypothalamic pep- 
tide hormones have been found in the extrahypothalamic organs as described above. All these data suggest that further studies are needed on the physiological role of these immunoreactive peptides.

Large amounts of immunoreactive LH-RF were detected in the extrahypothalamic area during pregnancy while serum levels of LH-RF during pregnancy were markedly lower as compared to those in normal menstrual cycle. The peaks of LH-RF in the sera were obtained at 10 minutes after placenta delivery among the different four stages of parturition, suggesting a significant change in endocrinological environments during parturition.

\section{ACKNOWLEDGEMENTS}

The author is deeply indebted to Professor Rihachi Iizuka, Chairman of the Department of Obstetrics and Gynecology, School of Medicine, Keio University, for his advice and encouragement during this study. He is also grateful to Assistant Professor Tsunehisa Makino, Department of Obstetrics and Gynecology, School of Medicine, Keio University, for his kind guidance and helpful suggestions throughout this work. The technical suggestions of the members of Otsuka Assay Laboratory are gratefully acknowledged.

Synthetic LH-RF was gifted by Sankyo Pharmaceutical Co. Ltd. LH-RF analogs were kindly provided by Dr. Noboru Yanaihara, Shizuoka College of Pharmacy. This study were presented at Sixth. International Congress of Endocrinology on February 15, 1980, Melbourne and also at the Annual Meeting of Japanese Society of Fertility and Sterility on October 1, 1980, Ube.

\section{REFERENCES}

1. Schally, A. V., Nair, R. M. G., Redding, T. W. et al.: Isolation of the luteinizing hormone and follicule-stimulating hormone-releasing hormone from porcine hypothalami. J. Biol. Chem. 246: 7230-7236, 1971

2. Monahan, M., Rivier, J., Guillemin, R. et al.: Synthese totale par phase solide d'um decapeptide qui stimule la secretion des gonadotropines hypophysaires $\mathbf{L H}$ et FSH. C. R. Acad. Sci. D. 273: 508-510, 1971

3. Nett, T. M., Akbar, A. M., Niswender, G. D. et al.: A radioimmunoassay gonadotropin-releasing hormone $(\mathrm{Gn}-\mathrm{RH})$ in serum. J. Clin. Endocrinol. Metab. 36: $880-885,1973$

4. Jeffcoate, S. L., Fraser, H. M., Gunn, A. et al.: Radioimmunoassay of luteinizing hormone releasing factor. J. Endocrinol. 57: 189-190, 1973

5. Arimura, A., Sato, H., Kumasaka, T. et al.: Production of antiserum to LHreleasing hormone ( $\mathrm{LH}-\mathrm{RH})$ associated with gonadal atrophy in rabbits: Development of radioimmunoassay for LH-RH. Endocrinology 93: 1092-1103, 1973

6. Rosenblum, N. G. and Schlaff, S.: Gonadotropin-releasing hormone radioimmunoassay and its measurement in normal human plasma, secondary amenorrhea, and postmenopausal syndrome. Am. J. Obstet. Gynecol. 124: 340-347, 1976

7. Neill, J. D., Patton, J. M., Dailey, R. A. et al.: Luteinizing hormone releasing hormone (LH-RH) in pituitary stalk blood of rhesus monkeys: Relationship to level of LH release. Endocrinology 101: 430-434, 1977 
8. Antunes, J. L., Carmel, P. W., Housepian, E. M. et al.: Luteinizing hormone releasing hormone in human pituitary blood. J. Neurosurg. 49: 382-386, 1978

9. Aksel, S.: Luteinizing hormone releasing hormone and the human menstrual cycle. Am. J. Obstet. Gynecol. 135: 96-101, 1979

10. Makino, T., Iwashita, M., Nakayama, A. et al.: Study on blood levels of luteinizing hormone beta subunit and LH-releasing factor in pregnant women. Keio J. Med. 29: $141-151,1980$

11. Youngblood, W. W., Humm, J. and Kizer, J.S.: TRH-like immunoreactivity in rat pancreas and eye, bovine and sheep pineals, and human placenta: nonidentity with synthetic pyroglu-his-pro- $\mathrm{NH}_{2}$ (TRH). Brain Res. 163: 101-110, 1979

12. Kumasaka, T., Nishi, N., Yaoi, Y. et al.: Demonstration of immunoreactive somatostatin-like substance in villi and decidua in early pregnancy. Am. J. Obstet. Gynecol. 134: 39-44, 1979

13. Upton, G. V. and Amatruda, T. T.: Evidence for the presence of tumor peptides with corticotropin releasing factor like activity in the ectopic ACTH syndrome. New. Engl. J. Med. 285: 419-424, 1971

14. Dubois, M. P.: Immunoreactive somatostatin is present in discrete cells of the endocrine pancreas. Proc. Nat. Acad. Sci. 72: 1340-1343, 1975

15. Wahlstrom, T. and Seppala, M.: Luteinizing hormone-releasing factor like immunoreactivity in islet cells and insulomas of the human pancreas. Int. J. Cancer 24: $744-748,1979$

16. Seppala, M., Wahlstrom, T. and Leppaluoto, J.: Luteinizing hormone releasing factor (LH-RF) like immunoreactivity in rat pancreatic islet cells. Life Science 25: 1489-1496, 1979

17. Makino, T., Takahashi, M., Yoshinaga, K. et al.: Ovulation blockade in rats by rabbit anti-luteinizing hormone releasing factor serum. Contraception 8: 133-145, 1973

18. Shiina, M.: Production of anti luteinizing hormone releasing factor (LH-RF) serum: Immunobiological application and development of radioimmunoassay. Japanese J. Fertil. Steril. 21: 464-473, 1976

19. Yokokura, T.: Study on anterior-pituitary function during pregnancy by radioimmunoassay of LH alpha, beta subunits. Japanese J. Fertil. Steril. 25: 24-31, 1980 (in Japanese)

20. Nakano, R., Kawashima, $F$. and Katayama, K.: The radioimmunoassay of follicule stimulating hormone (FSH) during human pregnancy: Serum concentration and response to luteinizing hormone releasing factor (LRF). Acta Obstet. Gynecol. Scand. 53: 263-265, 1974

21. Reyes, F. I., Winter, J. S. D. and Faiman, C.: Pituitary gonadotropin function during human pregnancy: Serum FSH and LH levels before and after LHRH administration. J. Clin. Endocrinol. Metab. 42: 590-592, 1976

22. Rubinstein, L. M., Parlow, F. A. and Derzko, C.: Pituitary gonadotropin response to LH-RH in human pregnancy. Obstet. Gynecol. 52: 172-175, 1978

23. Miyake, A., Tanizawa, O., Aono, T. et al.: Pituitary responses in LH secretion to LHRH during pregnancy. Obstet. Gynecol. 49: 549-551, 1979

24. Tojo, S.: Placental hormones. In: Endocrinologic obstetrics. Section 3. Nanzando Co. Ltd., Tokyo. 1977, 45-87 (in Japanese)

25. Aksel, S. and Tyrey, L.: Luteinizing hormone releasing hormone in the human fetal brain. Fertil. Steril. 28: 1067-1071, 1977

26. Siler-Khodr, T. M. and Khodr, G. S.: Studies in human fetal endocrinology I. Luteinizing hormone releasing factor content of the hypothalamus. Am. J. Obstet. Gynecol. 130: 795-800, 1978 
27. Baram, T. and Koch, Y.: Gonadotropin-releasing hormone in milk. Science 207: $315-317,1980$

28. Siler-Khodr, T. M. and Khodr, G. S.: Content of luteinizing hormone releasing factor in the human placenta. Am. J. Obstet. Gynecol. 130: 216-219, 1978

29. Khodr, G. S. and Siler-Khodr, T. M.: Localization of luteinizing hormone releasing factor in the human placenta. Fertil. Steril. 29: 523-526, 1978

30. Siler-Khodr, T. M. and Khodr, G. S.: Extrahypothalamic luteinizing hormone releasing factor (LRF): Release of immunoreactive LRH in vitro. Fertil. Steril. 32: 294-296, 1979

31. Khodr, G. S. and Siler-Khodr, T. M.: Placental luteinizing hormone releasing factor and its synthesis. Science 207: 315-317, 1980 